
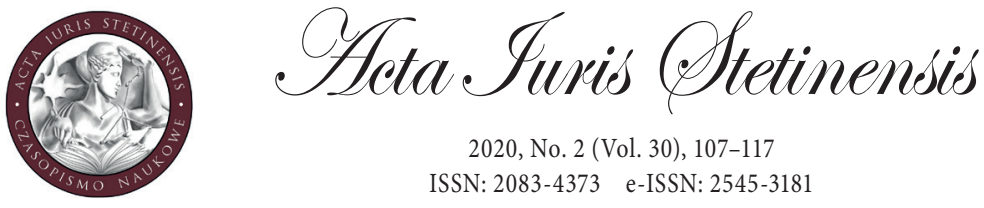

2020, No. 2 (Vol. 30), 107-117

ISSN: 2083-4373 e-ISSN: 2545-3181

DOI: $10.18276 /$ ais.2020.30-08

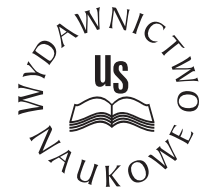

Małgorzata Żbikowska

Ph.D.

University of Szczecin, Poland

Faculty of Law and Administration

e-mail: malgorzata.zbikowska@usz.edu.pl

OPEN ACCESS

ORCID ID: 0000-0002-4792-4812

\title{
Essay on the manner of understanding truth in criminal proceedings
}

\begin{abstract}
The subject matter of the article is a short reflection on the concept of truth in criminal proceedings. The author raises the question about the manner of understanding the truth in a criminal trial, as well as about the relation of truth to proof and probability - are such concepts compatible, mutually exclusive or differentiated in terms of categories? As a result of such contemplation, the author decided that the text of Article $2 \$ 2$ of the Code of Criminal Procedure concerning material truth - in view of the today's criminal law scholars and commentators - is similar to the concept of ontological truth, i.e. the understanding of truth in a way that does not refer to the state of affairs only (ontic truth), but also to the statements and judgements made with respect thereto. Such an understanding of truth also allows one to acknowledge the fact that the truth and belief that a certain event (that needs to be proven or made plausible) occurred are two different epistemic categories.
\end{abstract}

Keywords: truth, principle of truth, material truth, ontic truth, ontological truth, substantiation/probability, paradox of truth 


\section{Introduction}

Addressing general issues, especially those that refer to general terms and - one may say - that are indefinite by nature (e.g. "justice" or "loyalty"), and trying to put them in the context of legal studies (even if it is only an attempt to tackle a given issue not to create a milestone of science) may often be unaccepted or even severely criticised. Why should we "put the cat among the pigeons" if it is possible to stay with the status quo? The aforementioned general terms include the concept of truth, and thus the truth in penal proceedings. The purpose of this article is neither to define the truth ${ }^{1}$ nor the truth in penal proceedings. The subject matter of the following, briefly outlined discussion shall be a reflection on the manner of understanding (perceiving) the truth in criminal proceedings in terms of contemporary legal dogmatic analyses. A reflection on the manner of understanding (perceiving) the truth in any context (e.g. in a criminal trial) does not have to be equivalent to the definition of truth. It is assumed that the contemplation on the understanding of a given concept may be in the form of describing it (or the way the concept is perceived), which is possible without a strict definition of such concept. ${ }^{2}$ The reflections regarding the understanding of truth in penal proceedings are most often tackled under a legal issue, which is referred to as a "nodal issue" of particularly profound social significance, constituting grounds for distinguishing the principle of material truth in the criminal law scholarship. According to some Polish legal commentators, the principle of material truth is considered the main focus of the criminal proceedings, ${ }^{3}$ which means that it represents meta-values with respect to the values forming a basis for other procedural rules. However, the truth in penal proceedings shall not be analysed in such a principled way (in view of the criteria for distinguishing the legal principles and rules of criminal proceedings). The concept of truth in penal proceedings may also be tackled from different perspectives,

1 Honestly, the author could not even imagine trying to define the concept of truth.

2 For instance, the author could describe her love for little, fluffy and purring pets with whiskers without actually explaining that such pets refer to the domesticated mammalian species of the order Carnivora, from the felid (cat) family.

3 To learn more about the subject, see Jodłowski, J., Zasada prawdy materialnej w postępowaniu karnym. Analiza w perspektywie funkcji prawa karnego, Warszawa 2015; Abdank-Kozubski, A., Problem prawdy w wybranych koncepcjach rozwoju nauki, "Studia Philosophiae Christianae" 1993, No. 1(29), pp. 171-178, including cited references. 
for example, by trying to answer the question about the nature of the discussed truth. The author tries to solve this problem in the subsequent parts of her study. ${ }^{4}$

\section{"Material truth" in a criminal trial}

The idea of truth has been the subject of many philosophical treatises, which contributed to the creation of numerous concepts of truth. ${ }^{5}$ J. Tischner wrote: "Apparently, the question arises as to what the concept of truth actually means. However, even in this case, there is no arbitrariness. Without going into the intricacies or details and remaining with the basic concepts only, we may state that the truth is the

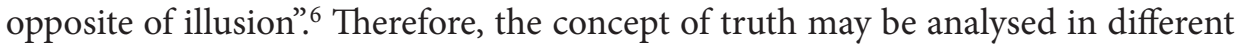
ways - from the logical perspective (the truth as the opposite of untruth) or from the metaphysical perspective (including a religious point of view). The issue of truth in penal proceedings has become the subject matter of statutory regulations. By virtue of Article $2 \S 2$ of the Code of Criminal Procedure, true findings of facts should constitute grounds for all court decisions. Literature shows that the abovementioned legal provision expresses the principle of material truth, which means that, first of all, it refers to certain events/facts, and second of all, it is opposed to formal truth (or court truth), which is established by procedural authorities on the basis of evidence, including the testimony of witnesses, regardless of the actual course of the event. ${ }^{7}$ What is more, it is also possible to issue various decisions in penal proceedings which are based on different actual events. The above may refer to the procedural decisions of a substantive (e.g. conviction or acquittal) and formal nature, including incidental decisions (e.g. decision to present charges - Article 313 of the Code of Criminal Procedure, decision to discontinue proceedings - Article 322 of the Code of Criminal Procedure, decision to reinstate a final date - Article 126 of the Code of Criminal Procedure). The grounds for a particular procedural decision may be the proof or probability, and thus a different degree of the procedural cognisance of the case by an adjudicating authority. With the above in mind,

4 It should be noted that this essay is based on the author's reflections on the probable and true findings included in her book Żbikowska, M., Ciężar dowodu w polskim procesie karnym, Warszawa 2019, pp. 331-337.

5 To learn more about the subject, see Zajadło, J., Teoretyczno - i filozoficzno-prawne pojęcie prawdy, in: Kremens, K. and Skorupka, J. (eds.), Pojęcie, miejsce i znaczenie prawdy w polskim procesie karnym, Wrocław 2013, pp. 8-24.

6 Tischner, J., Myślenie w żywiole piękna, Kraków 2013, p. 7.

7 In the context of further discussion, staying satisfied with such a differentiation between material truth and formal truth seems insufficient, and therefore, the grounds are rather vague. 
the question arises: what is the relation of truth to proof and probability - are such concepts compatible, mutually exclusive or differentiated in terms of categories? Simply put, the question is whether the findings that are only probable and probable to a different degree shall be considered true (accurate) in penal proceedings, and if so, what kind of model for understanding the truth should be adopted?

\section{Truth and probability}

Literature referring to the law of criminal procedure provides different answers to the aforesaid question. As an example, J. Nelken wrote: "Certitude should not be confused with truth, since these are two different terms. The truth is objective and exists independently of the knowing entity's awareness, whereas the certitude refers to a conviction about the truth learned in a specific case; thus, it constitutes a combination of objective and subjective factors and, hence, may sometimes be the result of an error". ${ }^{8}$ On the other hand, Z. Papierkowski wrote that the proof shall be deemed to mean "such a degree of certainty created in the mind or generally in the psyche of the entity examining certain circumstances, which would enable the entity to consider the said circumstances true. The feeling of being certain, i.e. a strong inner conviction, is the product of logical operations, which consist in correlating certain phenomena and drawing appropriate conclusions on the basis of the logical reasoning and experience". ${ }^{9}$ Moving on further, M. Cieślak indicated that the proof "may be treated as the grounds for perceiving a given assertion as true and the fact corresponding thereto as existing if it allows one to create a subjective absolute conviction about the truthfulness of the said assertion and an objective degree of probability which would be high enough to foster a strong conviction about the truthfulness of the proof in every person capable of reasonable judgement and comprehension." ${ }^{10}$ All of the above-mentioned representatives of Polish science distinguished two concepts - the certitude or conviction (subjective element) and the truth (objective element). Undoubtedly, the concept of the subjective conviction (belief) about the occurrence of a given event does not have to be equivalent to this event. Therefore, the differentiation between the subjective element and objective element has profound meaning, but it does not provide any answer to the question about the concept of truth discussed herein.

8 Nelken, J., Dowód poszlakowy w procesie karnym, Warszawa 1970, p. 77.

9 Papierkowski, Z., Dowód poszlakowy w postępowaniu karnym. Studium procesowo-prawne, Lwów 1933, pp. 2-3.

10 Cieślak, M., Zagadnienia dowodowe w procesie karnym, Warszawa 1955, p. 65. 


\section{Ontic truth and ontological truth}

When assuming that the truth is a somewhat objective feeling, it may be concluded that it does not reflect personal beliefs, presumptions or foreknowledge; hence, it must be presupposed that the truth exists independently of a person (ontic truth). It may also be theorised that the truth does not need a recipient or any confirmation that it is true (even though the question could be asked: does the truth need a recipient?). ${ }^{11}$ On the other hand, the concept of certitude may be considered a conviction (belief), and thus a subjective perception of reality. Therefore, the certitude may not exist without the recipient of reality, i.e. the entity that expresses such certitude. All beliefs are created due to something, so they have their basis, which means that there has to be the subject of the conviction concerned. Convictions in the form of certitude occur in penal proceedings as a result of an objectively verifiable evidentiary basis (a conglomerate of evidence collected in the case). Therefore, the conviction about the occurrence of a given event (subjective element) may be in line with the actual occurrence of such event (objective element - ontic truth). However, it may also not be in line with the actual occurrence of the aforesaid event. Such incompatibility may be unconscious (if it were conscious, it would be a lie). The theory of law includes a comprehensive discussion of the intellectual processes, which may constitute an efficient mechanism for explaining the manner in which the judicial body may discover the truth in penal proceedings. On the basis of the above reflections, the following passus should be invoked: “(...) the most important factors of the thinking process are certain illustrative (...) or non-illustrative presentations. Such presentations may be complete if expressed by logical sentences, which potentially include conjunctions and quantifiers, and fragmentary if expressed by a different sequence of words, in particular a single word - name. The presentations may be divided into those correlated with the convictions and those that have no such correlations. The first, and particularly important, category refers to the presentations, which - according to their participants - accurately reflect the reality, since the participants are convinced that the affairs are exactly the way they have been presented. The second, and insignificant, category refers to the presentations that do not reflect the reality, because they are not associated

11 If, for example, there are two witnesses in the penal proceedings, one of whom testifies that the defendant was riding a motorbike at excess speed, whereas the other one claims that the speed was within the permissible limit, and both witnesses are convinced that they are right (the difference lies in the different perspective of the event), it may be stated that both of them are truthful, meaning that they have testified to the truth (their truth). However, it is impossible to have two different truths regarding the same event. Therefore, does the truth (always) need a recipient? 
with any convictions that the reality is as it is". ${ }^{12}$ It seems that the thinking process of the adjudicating authority with respect to the criminal liability of the defendant (judgement) consists of the illustrative and complete presentations, which are also correlated with the conviction that a specific person is guilty of the alleged crimes. What is more, the aforementioned presentation correlated with the conviction means that the entity which has such a conviction believes that it accurately reflects the reality, and thus it is true. Therefore, the presentations correlated with the convictions may not actually be connected with the objective reality. In summary, ontic truth may represent various epistemic categories in a criminal trial, i.e. the objective occurrence of a given event and conviction about the occurrence of such an event or the (specific) probability of its occurrence.

As stated above, different decisions are issued in penal proceedings - both substantive and formal decisions. The probability of occurrence of a given event (e.g. high probability of committing a crime - Article $249 \$ 1$ of the Code of Criminal Procedure, sufficient proof of alleged or suspected crime - Article $313 \$ 1$ of the Code of Criminal Procedure) is often the only requirement for issuing a formal decision. Nonetheless, this does not mean that the concept of probability is connected with a possibility of adjudication based on "uncertain" or not necessarily "true" findings and, as a consequence, with the assumption that the Code of Criminal Procedure does not require certitude to issue a specific decision in the proceedings on the grounds of such probability. ${ }^{13}$ Literature shows that such a way of seeing the degree of the cognisance of the case by the adjudicating body leads to the conclusion that adjudication without "moral certitude" is possible. ${ }^{14}$ However, such an assumption would be contrary to Article $2 \$ 2$ of the Code of Criminal Procedure. In compliance therewith, all decisions should be based on true and accurate findings. The term "all decisions" refers not only to the decisions that must be proven, but also to those that must be made probable. It should also be mentioned that in the case of the authority issuing a specific decision in the proceedings, "the presentations correlated with the convictions of different degrees of certainty may occur. If the certainty is strong enough, the statements expressing the presentations correlated

12 Patryas, W., Próba wyjaśnienia domniemań prawnych, Poznań 2011, p. 17. See also: Patryas, W., Uznawanie zdań, Warszawa-Poznań 1987.

13 R. Kmiecik pointed to the risk of such understanding of the concept of substantiation in: Uprawdopodobnienie w procesie karnym, "Nowe Prawo" 1983, No. 5, pp. 45-46. A different position is adopted by Nelken, J. in: Uprawdopodobnienie w procesie karnym, "Nowe Prawo" 1970, No. 4, p. 519.

14 Kmiecik, R., Uprawdopodobnienie..., p. 46. 
with such convictions constitute the beliefs of the authority, unlike the suppositions expressing the presentations correlated with weaker convictions". ${ }^{15}$

Nevertheless, special attention should be paid to the fact that it is possible to specify the above-mentioned assumptions and state that they concern the facts (occurrence of a given event). Such certainty allows one to form the grounds for issuing a certain decision in the proceedings (occurrence of other elements required for said decision). Therefore, a specific conviction may concern the fact of committing a crime or imply the issuance of the decision to the present charges (Article 313 of the Code of Criminal Procedure), which requires only the probability that a given person is guilty of the alleged crimes. On the other hand, the certitude shall refer to the grounds for issuing such a decision in the proceedings. The truth in penal proceedings shall also include the findings, in which case, it is enough that they are probable. It has often been stressed in the legal academia that the "principle of objective truth refers not only to the proceedings aimed at resolving the dispute, but also to many incidental proceedings that are initiated during the criminal trial". ${ }^{16}$ With the above in mind, it is evident that both the proof and probability must be connected with the truth, but not the truth understood as complete compliance with the objective and unchanged state of affairs. If one expected "true findings" to include ontic truth, which is the truth of the "thing itself" or the "being itself", the adjudicating body would never be in a position where it is allowed to issue a specific decision in the proceedings, since such authority would never face the so-called ontic truth. The judicial bodies (court, prosecutor's office) may never be witnesses of illegal acts, with respect to which the proceedings are pending (Article $40 \$ 1$ point 4 and Article $47 \$ 1$ of the Code of Criminal Procedure). Therefore, it could seem that contrary to ontic truth, Article $2 \$ 2$ of the Code of Criminal Procedure refers to ontological truth, which means that such methods of understanding the truth that do not concern the state of affairs (ontic truth) but the statements or judgements about such a state of affairs. The concept of ontological truth may be understood as proper recognition of the already known object. Such an interpretation is confirmed by Article $2 \$ 2$ of the Code of Criminal Procedure by referring not to the facts (the facts are always true) but to the findings. However, even the aforesaid assumption is not that obvious.

15 Patryas, W., Próba..., p. 41.

16 Iżykowski, M., Charakterystyka prawna uprawdopodobnienia w postępowaniu cywilnym, "Nowe Prawo" 1980, No. 3, p. 75. 


\section{The paradox of truth}

With the above in mind, the question about when the findings may be considered true or not in criminal proceedings could emerge during such proceedings. On the basis of this discussion, it is evident that the subjective conviction (belief) about the truthfulness of the findings and objective certitude, i.e. objectively verifiable evidentiary basis, shall constitute the prerequisite for stating that the findings are true. Furthermore, there might but does not have to be coherence between the subjective conviction and objective certitude and the actual course of a given event. It is possible that according to the evidence collected in the case, the court may be convinced that the defendant - to obtain material gains - caused another person to dispose of their property in an unfavourable manner by misleading such a person, whereas in reality this was not the case. On the basis of the above example and the previous findings, it may be stated that the court's decision (judgement of conviction) would be in line with ontological truth. At this point, either the paradox of truth occurs in the criminal proceedings or the concept of truth proposed herein is not in compliance with the findings reached in the criminal proceedings. Therefore, the paradox of truth would mean, in this case, that the court's findings (subjective conviction and objectively verifiable evidentiary basis) shall be considered true (ontological truth), whereas they do not actually refer to any real situation. In light of the above, is it possible to talk about the "truthfulness" of the findings (truth understood in any manner)? Additionally, it should also be mentioned that the "classical" concept of ontological truth means that judgements about the things which actually exist are true; hence, the concept of ontological truth comes down to the correct recognition of a specific object. Therefore, if incorrect recognition of the object does not constitute ontological truth, what kind of truth is there in the criminal proceedings, and what is actually the difference between the principles of material truth and formal truth distinguished in literature? A different approach may be followed. Even if the "philosophical" debate on the truth in criminal proceedings were abandoned, and the emphasis was put solely on the construction of Article $2 \S 2$ of the Code of Criminal Procedure ${ }^{17}$ by creating an artificial and scholarly interpretation of the term "true findings", would it solve the problem?

17 The aforementioned concept would probably have to cover untrue findings as well - i.e. in the event when the court issues an untrue decision (e.g. the judgement of conviction according to which it is wrongly assumed that a given event occurred, whereas in reality it was not the case). It is normally assumed that the court's decision issued in penal proceedings is in line with material truth; however, this does not exclude the possibility of lodging appeal measures that may prove efficient. 


\section{Truth and certainty}

When coming back to the previous issue, the findings that have been proven and substantiated shall be considered - in light of the understanding of the concept of truth established in the literature - true findings of fact. The juxtaposition of the probability of occurrence of a specific fact with the truth would not be justified pursuant to Article $2 \$ 2$ of the Code of Criminal Procedure. The very concept of proof does not relate to the "objective certitude" about the facts, but refers to the highest degree of probability of their occurrence. The grounds for issuing the procedural decision, which needs to be proven, shall be the formation of the "subjective certitude", 18 expressed by the following formula: subject $\mathrm{O}$ is confident that a given fact has actually occurred, which means that such fact has been conceived by subject $\mathrm{O}$ and is deemed to be the actual fact. ${ }^{19} \mathrm{~A}$ similar situation takes place in the case of the procedural decisions that must be substantiated subject to the fact that the lower probability of occurrence of a specific fact is required for their issuance. As far as the probability is concerned, "subjective certitude" is also required with respect to the grounds for the issuance of such decisions. However, it must be noted that even though "subjective certitude" is required for the issuance of a specific procedural decision, it is created on the basis of the objective evidentiary proceedings. "Since the objectivity of the evidentiary proceedings shall have the same impact not only on the knowledge of the authority, but also of other parties involved in the proceedings, it is better to talk about the intersubjectivity of the evidentiary proceedings understood as the recurring subjective reaction of various persons" ${ }^{20}$

In conclusion, it may be stated that the degree of the cognisance of the case by the adjudicating body, which constitutes the substantiation of the assertion on the existence of a specific fact, should not be opposed to the truth within the meaning of Article $2 \S 2$ of the Code of Criminal Procedure. The findings that are probable, in compliance with the provisions of the Code of Criminal Procedure, shall also be considered true (according to some way of understanding it). However, one issue needs to be emphasised. The "subjective certitude" about the grounds for the issuance of the procedural decision does not have to be shared by all entities from the collective body involved in the issuance of such a decision. For instance, proof

18 A. Gaberle wrote in more detail about the concept of the "subjective certitude" in: Dowody w sadowym procesie karnym. Teoria i praktyka, Warszawa 2010, pp. 25-26; Kmiecik, R., Prawo dowodowe. Zarys wykładu, Warszawa 2008, p. 223.

19 Zieliński, M., Poznanie sądowe a poznanie naukowe, Poznań 1979, p. 77.

20 Patryas, W., Próba..., p. 55. 
of fault does not require all members of the adjudicating body to share the same conviction, but only the majority thereof, which shall reflect moderate epistemic individualism. ${ }^{21}$ The above also results from the wording of the provision of Article 111 of the Code of Criminal Procedure, according to which the decisions are made by a majority of votes cast, and Article 112 of the Code of Criminal Procedure, according to which the judge who voted against finding the defendant guilty may abstain from voting on further issues; in such a case, the vote cast by the judge is "attached" to the opinion most favourable for the defendant. Therefore, the defendant may be found guilty of the alleged crimes even in the event when one of the members of the adjudicating body is convinced of the innocence of the defendant. Such a belief - in the case of the collective body of the court - shall not be deemed to mean that the issued decision (in this situation - the judgement of conviction) is at variance with the principle of material truth mentioned in literature (Article $2 \S 2$ of the Code of Criminal Procedure). The foregoing is prejudged by the previous assumption that - in connection with Article $2 \$ 2$ of the Code of Criminal Procedure - it is possible to talk about the truth in the context of opinions and judgements about specific states of affairs, but not about the states of affairs as such. The text of the principle of material truth is related to all decisions, and thus not only the decision on finding the defendant guilty, as well as to formal decisions.

\section{Conclusion}

In conclusion, the principle of material truth in criminal proceedings does not express ontic truth, and thus the truth of the "thing itself" and the "being itself". What is more, it should also probably not be understood as the classical ontological truth, ${ }^{22}$ which consists in the appropriate recognition of a specific object despite the fact that it is based on opinions and judgements. According to the author, there is still no answer to the question about the method of understanding the truth in a criminal trial and the potential solution of the paradox of truth pursuant to Article $2 \$ 2$ of the Code of Criminal Procedure, which means that certain findings are considered true even if they are actually not.

21 See Patryas, W., Próba..., p. 46 and Uznawanie..., p. 209.

22 With the above in mind, the author decided to modify her approach presented in the book entitled Ciężar dowodu..., op. cit. 


\section{References}

Abdank-Kozubski, A., Problem prawdy w wybranych koncepcjach rozwoju nauki, "Studia Philosophiae Christianae" 1993, No. 1(29).

Cieślak, M., Zagadnienia dowodowe w procesie karnym, Warszawa 1955.

Gaberle, A., Dowody w sadowym procesie karnym. Teoria i praktyka, Warszawa 2010.

Iżykowski, M., Charakterystyka prawna uprawdopodobnienia w postępowaniu cywilnym, "Nowe Prawo" 1980, No. 3.

Jodłowski, J., Zasada prawdy materialnej w postępowaniu karnym. Analiza w perspektywie funkcji prawa karnego, Warszawa 2015.

Kmiecik, R., Uprawdopodobnienie w procesie karnym, "Nowe Prawo" 1983, No. 5.

Kmiecik, R., Prawo dowodowe. Zarys wykładu, Warszawa 2008.

Kremens, K. and Skorupka, J. (eds.), Pojęcie, miejsce i znaczenie prawdy w polskim procesie karnym, Wrocław 2013

Nelken, J., Dowód poszlakowy w polskim procesie karnym, Warszawa 1970.

Nelken, J., Uprawdopodobnienie w procesie karnym, "Nowe Prawo” 1970, No. 4.

Papierkowski, Z., Dowód poszlakowy w postępowaniu karnym. Studium procesowo-prawne, Lwów 1933.

Patryas, W., Uznawanie zdań, Warszawa-Poznań 1987.

Patryas, W., Próba wyjaśnienia domniemań prawnych, Poznań 2011.

Tischner, J., Myślenie w żywiole piękna, Kraków 2013.

Zajadło, J., Teoretyczno - i filozoficzno-prawne pojęcie prawdy, in: Kremens, K. and Skorupka, J. (eds.), Pojęcie, miejsce i znaczenie prawdy w polskim procesie karnym, Wrocław 2013.

Zieliński, M., Poznanie sądowe a poznanie naukowe, Poznań 1979.

Żbikowska, M., Ciężar dowodu w polskim procesie karnym, Warszawa 2019.

\section{CITATION}

Żbikowska, M., Essay on the manner of understanding truth in criminal proceedings, "Acta Iuris Stetinensis" 2020, No. 2 (Vol. 30), 107-117, DOI: 10.18276/ais.2020.30-08. 